\title{
SAUSSURE AND THE POLITICAL POTENTIAL OF LANGUAGE
}

\author{
Min Seong Kim Kepartment of Religious and Cultural Studies $^{1}$ \\ Sanata Dharma University \\ Yogyakarta, Indonesia
}

\begin{abstract}
:
Although the linguistic theory of Ferdinand de Saussure is widely recognised as the forerunner of structuralism, it is often treated in the humanities and social sciences today as a stepping stone toward more sophisticated, generalised semiotics and theories of discourse. As a result, social and political implications of Saussure's original conception of language have frequently been underestimated. Drawing from the classic lecture Course in General Linguistics and the fragmented notes collected in Writings in General Linguistics, this article offers a reconstruction of the social and political dimensions that were present, albeit in an inchoate form, within Saussure's own theorisation. To act as a foil to the reconstructed Saussurean position, this article calls upon an essay that charts the historical development of the concept of discourse authored by Ernesto Laclau, who is perhaps the most politically oriented thinker among the many inheritors of the Saussurean legacy.
\end{abstract}

\section{Keywords:}

structural linguistics - structuralism • poststructuralism • political theory • hegemony - discourse theory • Ferdinand de Saussure • Ernesto Laclau 
In a short essay that traces the historical development of the concept of discourse, Ernesto Laclau offers the following assessment apropos the limitations of Ferdinand de Saussure's linguistic theory:

In a Saussurean perspective, a linguistics of discourse is impossible because a succession of sentences is only governed by the whims of the speaker and does not present any structural regularity graspable by a general theory. With this Cartesian assertion of the omnipotence of the subject, the very possibility of linguistic theory of discourse was ruled out. ${ }^{2}$

Exemplified by Laclau's assessment is a common tendency in the humanities and social sciences that, whilst recognizing Saussurewho himself rarely spoke of 'structures' - as the founder of structural linguistics and the forerunner of structuralist thought, treats his thought as little more than a stepping stone toward more recent, sophisticated, and generalized semiotics and theories of discourse associated with names such as Roland Barthes, Jacques Lacan, Jacques Derrida, Julia Kristeva, and, of course, Laclau himself. The heavy emphasis placed on post-Saussurean developments inevitably tends to downplay the distinctive understanding of language as intertwined with the social and the political that can be glimpsed in Saussure's own presentation of his linguistic theory. ${ }^{3}$

The attribution of 'Cartesian omnipotence' to the Saussurean subject in Laclau's assessment is apparently founded on a summary judgment that the Saussurean subject is incompatible with the 'dislocated' subject announced by a poststructuralist approach such as Laclau's own-namely, the subject whose utterances are conditioned by the structure-that allows for the reimagination of socially transformative political processes as material practices that reshape the social conditions of subjectivity, hence the identity of the subject, in ways that are supposedly unthinkable within Saussurean theory. Claiming thus that the Saussurean subject is in principle able to utter anything in language it wishes whenever it so wishes, Laclau suggests the specific content of its utterances as determined by irregular and unpredictable 'whims'. However, although it is true that Saussure sometimes imputes an 'unlimited freedom' to the speaker in the 'articulation' of syntagms or sentences, ${ }^{4}$ a closer examination problematizes the characterization of the speech of the Saussurean 
subject as 'governed' solely by its whims. While the innovations in structural linguistics (Roman Jakobson and Louis Hjelmslev counting amongst the most important contributors) that have been indispensable for a sophisticated theorization of discourse must be acknowledged as such, Saussure's original insights may be interpreted in a way that brings out a surprising degree of continuity with the kind of poststructuralist discourse theory that Laclau himself has developed, to the extent that what he characterizes as Cartesian omnipotence and whims-connoting a sort of unconditioned power to speak anything, whenever-could be shown to correspond to the margin of freedom in thought that is not incompatible with the theoretical commitments of Laclau's own discourse theory.

Through a reconstruction of a Saussurean position based on Saussure's lectures and the edited volume of his notes that answers to the issue raised by Laclau, it will be shown that the construction of syntagms by a speaker can be apprehended in a way that allows the subject positions with which the speaker identifies herself to be seen as influencing what can be said and what is said by the speaker. If, based on his theorization of discourse, Laclau proposes to understand politics as consisting in attempts to reconfigure the field of the social by a plurality of forces each striving to attain a hegemonic or universal status, then in Saussure's vision of language, there is a 'politics of language' that consists in heterogeneous language systems-langues-perpetually in interaction, effecting reconfigurations in the plurality of langues that comprise what may come to be seen, and experienced, as one common language. That Saussure was a poststructuralist discourse theorist avant la lettre is a proposition that this paper has no intention of defending. Nor will this paper advance the obverse proposition, suggested by Peter Caws, that the move toward poststructuralism and semiotics after Saussure was 'regressive'. ${ }^{5}$ What this paper does hope to show, rather, is that there is an intersection of language and politics in Saussure's own thought, at which its proximity to Laclauian discourse theory and the politics of hegemony Laclau has elucidated is clearly discernible. 


\section{The Exposure of Langues to Time and Alterity}

Beginning with the common understanding that a sign is 'conceived as a relation between an acoustic image (the signifier) and a concept (the signified)', Laclau proceeds to summarize Saussure's 'basic principles around which structural linguistics is organized' as follows: (1) in language, 'there are no positive terms, only differences'; (2) language is 'form and not substance', such that 'each element of the system is exclusively defined by the rules of its combinations and substitutions with the other elements'. In the 'entirely differential universe' that Saussure had postulated, Laclau goes on to claim, 'there is strict isomorphism: to each stream of sounds constituting a word corresponds one and only one concept. The order of the signifier and the order of the signified strictly overlap'. ${ }^{6}$ However, if there is no substance in language but only forms, and yet there is a strict isomorphism between the stratum of the signifier and the stratum of the signified, then the result can only be the collapse of the duality of the sign. This collapse, Laclau contends, is averted in the Saussurean text only by the 'surreptitious' introduction of the substantial difference between the phonic and the conceptual. But if this is the kind of difference on which the duality of the sign effectively stands, the fundamental principle that language concerns forms and not substances is already undermined in Saussure's own conceptualization of the sign. This, Laclau asserts, is the 'ultimately inconsistent' nature of the Saussurean sign.

As a historical narrative of the development of the concept of discourse would dictate, Laclau notes, accurately, that inheritors of Saussure's basic principles both within and beyond linguistics have insisted on the primacy of the signifier, viewing the signified-or, as is perhaps more accurate by this point, signification - as the effect of signifiers. Had the order of signifiers not been liberated from the signified qua conceptual substance, the kind of generalized semiotics that Saussure himself envisioned would not have been possible. This poststructuralist commonplace, however, is not the fairest point of departure for approaching Saussure's thought. This is because the claim that there is a strict isomorphism between the differential relations at the stratum of signifieds and at the stratum of signifiers such that the distinction between the strata finally collapses can only be asserted by suppressing two aspects that are integral to Saussure's understanding of 
language, namely, the dimension of time and the irreducible communality of language. In fact, it is a re-examination of these aspects that opens the possibility of responding to the charge of 'inconsistency' against Saussure's conceptualization of the sign.

In the particular langue that is instantiated in what Saussure refers to as the individual speaker's 'mind' by the speaker's particular utterance or parole, it may indeed be the case that the orders of signifiers and signifieds are isomorphic. This is simply because the thought of a sign is nothing other than that of a concept materialized in sound. In beginning to elaborate the counterclaim that this isomorphy - and the consequent collapse of the division between the two orders - is not, however, the end of the story, two points are worth noting. Firstly, when a concept is said to attain a coupling with an acoustic image, the concept in question is neither an eternally existing nor a 'naturally available' concept-concepts implicated in signs have to do neither with ideas that are individuated at the heights of the Platonic heaven nor differentiated substances present on the Aristotelian earth. Not unlike the real that Lacan describes as the "noise in which one can hear anything and everything', concepts considered independently of their constitutive relation to signs can only be posited as a 'shapeless and indistinct mass' of thought. ${ }^{8}$ The possibility of meaning, dependent on the differential order of signifieds, does not precede the institution of a system of differences, which in Lacanian theory is conceptualized as the intervention of the symbolic, and in Saussurean linguistics, as langue. Secondly, langue, while designating that system of difference in its synchronicity, is nonetheless said to be 'ever on the move, pressed forward by its imposing machinery of negative categorization'. ' The second point is crucial for this paper: a response to Laclau's claim that the duality of the sign collapses in Saussure's conception of the coupling of a signifier with a signified shall be developed through the examination of how the 'movement' of langues is conceived in the Saussurean text, without attributing to the 'shapeless and indistinct mass' of thought a capacity for self-movement or self-differentiation.

Kojin Karatani's reading of Saussure's linguistic theory in Transcritique provides a valuable point of departure for the abovementioned examination. Saussure's 'conviction', Karatani writes, 'was that in language there are only differences; it is a system of pure value'. ${ }^{10}$ Karatani contends 
that 'these statements could not have been said had he thought within a unitary system (i.e., of a langue)', for Saussure

introduced the concept of value only when he took into consideration another system of Langue: Saussure's point is that when a word is translated into another language, it achieves the same meaning, yet at the same time, the value of the world is altered in the new/different system in correspondence to its different relationship with other words. From this focal point, he explains that there is no meaning (the signified) that is apodictically tied to the signifier, in other words, no immanent meaning. 11

The implication, firstly, is that instaurations and disappearances of terms in a langue - that is, changes within a language system—can happen as a result of its interaction with other langues that differ from it. But more importantly, that Saussure found it necessary to introduce the concept of value as distinct from meaning (signified) when 'manifold/different systems are at stake' opens the possibility of a reading that reverses the one followed by Laclau by making the plurality of systems (langues) into an irreducible, constitutive dimension of the Saussurean concept of language. This alternative reading-which chooses to regard as an innovation that which Jakobson saw as a symptom of Saussure's confusion, namely, the concept of value-allows that the isomorphism between the order of the signifiers and the order of the signifieds to be asserted as Laclau does, but only when language is considered solely in its synchronic and solipsistic dimension, as 'one synchronic system'. However, in as much as the plurality of langues is constitutive of language in the Saussurean conception as the alternative reading proposes, the isomorphism of the signifier and the signified-and the alleged collapse of the distinction between the two orders - can be placed under question.

The reversal on which the alternative reading is based is enabled by the fact that the Saussurean proposition that language is social means neither simply that language is 'a fait social (Durkheim) beyond individual consciousness' nor that 'individual terms exist only in a larger relational system'. ${ }^{12}$ Rather, as Karatani rightly asserts, Saussure's claim is that 'language is properly social only when it is seen as, and in, communication with the other-with those others who belong to other systems of rules (langues) or communities'. ${ }^{13}$ The first step toward understanding this claim involves 
tying together the sociality of language and the shift in the relationship between the terms of a langue - the idea that if a given term were to drop out of the system [...] its contents would go to its competitors ${ }^{14}$ - as a consequence of the former. Suppose that a person enters conversation with a botanist whose langue contains more terms than that person in the field of botany. It is supposable that 'mass' of thought — that is, the stratum of concepts or signifieds-concerning plants is intricately differentiated for the botanist who commands a great number of terms apropos botany, whereas the botanist's interlocutor, possessing only a handful of terms to speak about plants, has a relatively less differentiated set of concepts pertaining to plants. If the botanist were to introduce a new term to the interlocutor's vocabulary that pertains to plants, the latter's conceptual mass would 'cut up' into more pieces, into finer-grained distinctions, resulting in a greater number of differential relations - though it will likely remain the case the way that the interlocutor's concepts is differentiated will not match the botanist's, as long as the botanist continues to possess more terms, hence finer conceptual distinctions, than the interlocutor.

The preceding example begins to sketch the process that Saussure calls the 'negative action of signs'. ${ }^{15}$ For Saussure, a new sign is never a 'direct' introduction of a new positive idea, but the introduction of a new sign does effect a reconfiguration or repartition of the mass of thought, or concepts, that is the order of the signifieds. Hence, the 'number of positive ideas which a sign must cover at a given moment is therefore never limited. Its limit may only be negative, drawing on the simultaneous presence of other signs. It is thus pointless to seek the totality of a word's meanings' ${ }^{16}$ The 'permanent condition of language [les conditions permanentes de la langue]' is such that 'if you add a sign to the language system, you proportionally diminish the meaning of the other signs [si vous augmentez d'un signe la langue vous diminuez d'autant la signification des autres]. Conversely: if, per impossibile, only two signs had been chosen in the beginning, all meanings [toutes les significations] would have been distributed [réparties] among these two signs. One would have designated [désigne] half the objects, and the other the other half'. ${ }^{17}$ The stage on which 'change, varying degrees of shifts in the relationship between the signified and the signifier' often takes place is where interactions between heterogeneous langues occur, namely, the 
community of language users. ${ }^{18}$ Neologisms, for example, begin their lives within small coteries of users, and then gradually gain wider usage. At the beginning, the small group of speakers for whom the neologism was present in their langue would have been attuned to a langue that is different from the langue shared by the rest of their linguistic community. Only later may the new sign enter wider circulation and reconfigure a wider range of langues in the community.

The analysis of the sign as divided between the orders of the signifier and the signified enables structural linguistics to account for the kind of transformation described above in the langue of an individual, in which one and the same signifier, from an initially more 'extensive' distribution of a conceptual mass (that is, the 'number of positive ideas' that a sign covers), becomes coupled with the less extensive distribution of the conceptual mass (the converse of which also may happen), without recourse to a naturalistic referential theory of meaning. The langue that is instantiated by an individual's act of speech is synchronically analysable in terms of the dual strata of differences that are, as Laclau had claimed, isomorphic, to the extent that in a sign, a signifier is coupled with a particular part of a conceptual mass, one signified. But if there are heterogeneous langues in interaction, as it was the case for the botanist and the interlocutor in the example earlier, and if this interaction really is a 'permanent condition of language' as asserted by Saussure, then it follows that the Saussurean account is one in which the relation between signifiers and signifieds is permanently and inescapably exposed to the possibility of shifts due to the heterogeneous langues of different groups of speakers with which a speaker comes into contact. Interacting with another langue is able to produce altered relations between signifiers and signifieds of the langue of a speaker, so that one and the same acoustic image, although still coupled to some particular part of the speaker's conceptual mass, nevertheless will have coupled with a part that—due to its differing extensiveness and positionality - can no longer be considered the same as the part prior to that interaction. Systematization of a langue into a particular synchronic formation is conceivable precisely as achieved in the instance of an interaction (with another speaker), which must necessarily instantiate a particular langue as a systematic totality. But that such instantiation in interaction is the origin of any particular langue implies that the 
synchronicity of a langue is exposed to the diachronic dimension by which the effects of encounters with other langues will have inscribed themselves in that langue, possibly as new signifiers and reconfigurations of concepts. It would not be far-fetched, at this point, to suggest that the possibility of what Laclau conceptualizes as 'dislocation' is not alien to the Saussurean sign-a possibility that will become clearer once the irreducibly social existence of language is considered in more detail.

\section{The Irreducibly Social Being of Language}

In the example of the botanist and her interlocutor, an overlap between the langue of the botanist and the interlocutor's langue is implied by their ability to meaningfully interact and produce sounds that are not perceived as mere noise to each other. But the example also evinces that the overlap certainly need not be total for their conversation to be possible. Extrapolating from this, a proliferation of heterogeneous langues in a community that purports to speak one and the same language can easily be entertained. Saussure writes that there is 'no precise point marks the beginning of one language and the end of another'. ${ }^{19}$ 'The limit of even just one language is never identifiable with the set of any number of langues that are believed to compose it-even if that non-identity is due merely to the supernumerary attachment of the proper name of the language ('English', 'German', etc.) to a given set of langues, sometimes motivated by, as Saussure suspects happened with Italian, apparently extra-linguistic influences such as 'national will'. ${ }^{20}$ The non-identity between any set of langues and any purported totality of a language applies conversely as well: no one langue has a legitimate claim to being the privileged and complete embodiment of a language. Neither actual nor ideal unity of a language needs to be posited in the Saussurean conception. But if it is neither actual nor ideal unity, what is the being of (one or another) language? The response that is consistent with what has hitherto been argued is clear: language is irreducibly social, from which it follows that a language always comprises a plurality of heterogeneous langues. No one langue can serve as the exclusive representative of a language. To hope to elevate one langue as the full embodiment of a language would be a dream comparable to the hope for a fully homogenous and self-identical community — the ideological fantasy 
par excellence. Language, Saussure asserts, 'is not complete in any speaker; it exists perfectly only within a collectivity'. ${ }^{21}$ This assertion is to be read with an emphasis on being: a language is 'perfect' when it is irreducibly social, that is, when it comprises a plurality of heterogeneous langues.

If speaking the same language does not imply sharing an identical langue, then it is possible to think of the variances among langues of various groups of individuals, variances that would obtain by virtue of the differences between the groups' positions in the space of the social. This thought, by suggesting that utterances may be conditioned by the speaker's subject position, already marks a significant departure from seeing a speaker's utterances as merely outcomes of unpredictable and unregulated 'whims'. Indeed, herein is one point of intersection between the Laclauian theory of discourse and Saussurean linguistics. The 'basic proposition' of Hegemony and Socialist Strategy identified by Slavoj Žižek, namely, that 'Society' — as a harmonious and totalizable whole_-'doesn't exist', ${ }^{22}$ is comparable to the Saussurean view that a linguistic community is not a community of one and the same langue. If, for Laclau, the plurality of discourses and positions that compose the social prevents the social from constituting itself as a harmonious and unified whole, then the Saussurean account recognizes that the 'minds' of individuals on which a portion of language is imprinted should vary according to differences in the positions of those individuals. In so far as there is no unified social totality, there is no unified totality of speakers all of whom instantiate the same langue in their speech. What needs to be made explicit is the political implications of this outcome.

While considering the mechanism by which languages become fragmented and diversified, Saussure imagines a situation wherein people from other places pass through a village, and some from that villager travel to some other village, and so forth. Reflecting on such 'interaction', Saussure notes that 'difference according to locality is both an illusion and a reality. It may or may not occur, but it is impossible to predict this for a given detail'. ${ }^{23}$ The occurrence and details of a particular interaction cannot be determined in advance by linguistic theory. What can be offered, nevertheless, is a theoretical proposition on the 'forces' that operate within a language due to interactions between different groups of people, that is, due to its social existence: 'two principles are forever in opposition, one 
an equalizing force, the other particularizing. Divisive influences/Unifying influences [...] resisting cobesion'. ${ }^{24}$ Discernible in Saussure's text is thus an insight that begins to approach Laclau's theorization of the dislocation of discourses, that no hegemonic discourse, however stable it may be, achieves a complete fixity of social meanings or of relations between subject positions, because the condition of possibility of every discourse is the simultaneous presence of contradictory relations of 'equivalence' and 'difference' that renders, as a result, a discourse as a systematic totality whose elements are fixed an impossible object comparable to a 'square circle'. ${ }^{25}$

Even though Saussure's own text does not contain the theoretical elaboration needed to rigorously establish the irreducibility and ineliminability of a plurality of langues as ontological conditions, it is not difficult to recognize at this point the kernel of Saussure's reflections that no poststructuralist inheritor of his thought, including Laclau, can deny: in so far as there is a plurality of heterogeneous langues in reality, the latent potential for the reconfiguration of langues through interaction is to be thought as practically ineliminable. A language that is entirely hegemonized by one langue is in reality impossible, for the irreducible sociality of language entails that the heterogeneity between langues that are instantiated by various groups of speakers persists, exerting both particularizing and unifying influences on the community of language speakers, preventing its final closure. If political practice aims toward hegemony through the universalization of a particular discourse or representation of a particular social identity as universal, then, from a Saussurean perspective, political practice is to be seen as underlain by attempts to change the minds of individuals by inscribing a particular langue in a language community. In other words, if the social is a space of contention between different political discourses to attain a hegemonic status, then language can similarly be seen as a domain of contention between various langues, some of which are trying to impose its system of differences onto the orders of signifiers and signifieds instantiated by the linguistic acts of as many speakers as possible, without, however, ever being able to eliminate the heterogeneity of the community completely-whatever success actually achieved by attempts to hegemonize language will always be temporary. The remainder of this paper shall further explore this confluence of the hegemonic 
reconfiguration of the space of the social and the reconfiguration langues of a language community.

\section{Difference, Opposition, Association}

In a crucial passage, Saussure explains that, when brought into circulation as signs, differences in the strata of signifiers and signifieds are converted to oppositions between a sign and other signs:

When we compare signs-positive terms-with each other, we can no longer speak of difference; the expression would not be fitting, for it applies only to the comparing of two sound-images, e.g. father and mother, or two ideas, e.g. the idea 'father' and the idea 'mother'; two signs, each having a signified and signifier, are not different but only distinct. Between them there is only opposition. The entire mechanism of language, with which we shall be concerned later, is based on oppositions of this kind and on the phonic and conceptual differences that they imply. ${ }^{26}$

It has become a structuralist platitude that 'two things can $[. .$.$] be$ differentiated from one another only to the extent that they are opposed to the other'. ${ }^{27}$ As any two signs must be differentially positioned, it follows that there is a minimal and yet absolute non-identity between any two signs - this is a trivial point. But opposition does not follow trivially from difference. 'Bourgeoisie' is not 'proletariat', but the opposition between the two cannot be deduced from the mere fact that the former signifier is not identical to the latter. Instead, it is the retrospection of the historical events surrounding groups that have been designated thus that establishes the two terms as oppositional terms. The thinkability of opposition between signs, therefore, presupposes each sign as having attained a kind of self-identity ascribable to it, that is, a particular relation between a signifier and a signified instead of some other relation-a relation whose determination, as has been argued previously, is profoundly affected by the sociality of language. Value, which Karatani had pointed out was introduced by Saussure as a category distinct from the signified when considering the irreducible social dimension of language, pertains precisely to this self-identity achievable in a sign, in as much as it is in circulation along with signs that may originate in autre langues. And this achievement of self-identity is the only sense in which a sign can be said 
to be a 'positive term' without betraying Saussure's own 'basic principles' of linguistics.

The shift from the difference between signifiers and between signifieds to the opposition between signs is indicative of the mechanism of the actualization of a particular utterance over others. Conceiving actual utterances necessitates the conceptual shift because differences in the orders of the signifier and the signified do not yet account for the selfidentity achieved as the coupling an actual utterance instantiates between a particular signifier and a particular signified. That the mechanism is termed 'opposition' is not accidental, for the instance of one sign in 'actualized parole — an utterance_-implies that a particular 'potential parole' has prevailed by repressing the actualization of all other possibilities that had been available in the 'group of elements created and associated in the [speaker's] mind'. ${ }^{28}$ 'The logic of actualization that always implies the negation of what Saussure calls 'competitors', that is, the other 'potential elements' that could have entered an utterance, operates between signs however conceptually and phonically proximal within the differential system of that langue the signs may be to another. ' $A$ as opposed to $B$ ' is thus the 'entire mechanism' by which language instantiates itself materially. In reality, there are ambiguities, polysemes, and an overall degree of confusion to language, blurring, as it were, lines of opposition between terms. That there are ambiguities and polysemes and inaccuracies in language is simply the facticity of language and does not constitute an interesting observation. As Saussure writes, '[c]omplaining about the inaccuracy of language' merely 'suggests ignorance of the source of its power. It is quite impossible to prevent a single, specific thing being variously referred to as a house, a construction, a building, a structure'. ${ }^{29}$ The interesting question, rather, is what makes it possible, in a particular context or situation, for a term (e.g. 'building') to be interchangeable with others (e.g. 'construction', 'structure', etc.). It is this question that is addressed by the notion of association.

When presented with two terms whose signifieds are relatively coextensive (i.e. cover overlapping parts of the conceptual mass), there is a reduction in the range of available options when the speaker has to decide on one out of many possible terms. Thus, in a certain situation, the terms could be more or less interchangeable - a phenomenon that 
Saussure intended to grasp with the category of value-for the speaker in question. For a human person can simultaneously belong to a plurality of situations, although there is always opposition between signs, relative co-extensiveness of the conceptual mass with which those are coupled is not unthinkable. The converse also holds: the terms that would be interchangeable in certain situations may not be in others. Although lines of opposition between terms such as 'structure', 'building' and 'construction' may be more blurred when there is interchangeability in a plurality of situations, opposition becomes clearer in situations where the terms are not interchangeable. As terms that may be 'picked out' in an act of utterance, these terms comprise potential parole. They are imprinted on the speaker's mind, forming 'associative families' each composed of terms that are somehow related:

Those that have something in common are associated in the memory, resulting in groups marked by diverse relations. For instance, the French word enseignement 'teaching' will unconsciously call to mind a host of other words (enseigner 'teach,' renseigner 'acquaint', etc; or armament 'armament', changement 'amendment', etc. ; or education 'education', apprentissage 'apprenticeship' etc.) All those words are related in some way. ${ }^{30}$

The absence of detailed explanation as to why a certain term calls to mind a particular set of other terms is a lacuna that readily invites the kind of view held by Laclau, that the sentences of the Saussurean subject is governed by its whims. On the one hand, it seems to be phonetic propinquity (enseignement, justement...) that influences the set of other terms that is recalled, while on the other hand, it appears as if conceptual overlap-'analogy of the concepts signified', as Saussure puts $i^{31}$ determines the terms that belong to a same associative family (enseignement, instruction, apprentissage, éducation...). In the end, it must be said that the type of relation that ultimately prevails in a given parole will, again, be dependent on the situation - the Freudian text abounds with case studies of either. But in an interpersonal, social situation, it seems plausible to assume that a speaker's considerations regarding the interchangeability of terms in a given syntagm or sentence are likely to be reliant more on the conceptual rather than on the acoustic aspect of signs. If so, though it may not be the exhaustive picture, at least a partial explanation as to how an associative family forms has already been provided by the preceding exposition: terms 
in an associative relation are recalled based on their conceptual proximity that pertains to the co-extensiveness of the conceptual parts to which those terms are related. At this point, the key remaining task is to make explicit the proximity between the Laclauian theory of hegemony and Saussurean linguistics that is implied by the results so far, thereby bringing to the foreground the political implications of the latter.

\section{The Confluence of Saussurean Linguistics and Laclauian Hegemonic Politics}

'If the abstract system of formal rules governing the combination and substitution between elements is no longer necessarily attached to any particular substance', Laclau writes, 'any signifying system in society $[\ldots]$ can be described in terms of that system'. ${ }^{32}$ The strict formalism of this approach implies that 'substantial differences between the linguistic and the non-linguistic have also to be dropped'. ${ }^{33}$ The theoretical outcome of the abolition of the substantial difference firstly within language, and then between the linguistic and the non-linguistic, is observed when Laclau and his collaborator Chantal Mouffe define 'discursive structure' not as a 'merely "cognitive" or "contemplative" entity', but as 'an articulatory practice which constitutes and organizes social relations'. ${ }^{34}$ Since substantial differences between the linguistic and the non-linguistic are no more, articulation, too, is liberated from its ties to specifically linguistic utterances, and comes to designate 'any practice establishing a relation among elements [i.e. entities that possess discursive positionalities] such that their identity is modified as a result of the articulatory practice'.$^{35}$ And because Laclau and Mouffe 'reject the distinction between discursive and non-discursive practices', ${ }^{36}$ constitution as an object of discourse through articulation is, for them, the process of the constitution of objectivity in general. In the general ontology of Hegemony and Socialist Strategy, a work representative of a phase of Laclau's thinking prior to the later influence of the Lacanian theory of the subject, even the category of subject comes to be understood primarily 'in the sense of "subject positions" within a discursive structure'- that is, in terms of discursively constituted objects. ${ }^{37}$

The conceptualization of the subject in Hegemony and Socialist Strategy, then, reflects an Althusserian conception of the subject as 'material 
actions inserted into material practices governed by material rituals which are themselves defined by the material ideological apparatus from which derive the ideas of that subject'. ${ }^{38}$ What is termed 'articulation' by Laclau and Mouffe encompasses social rituals and practices in general, including specifically verbal articulations that are no longer categorially distinct from 'material actions' in the Althusserian sense. Thus, while the substantial dichotomy between the strata of the signifier and the signified is denied by Laclau, who asserts that, in his system, 'there are only signifiers', ${ }^{39}$ speaking of 'signifieds' is acceptable for him in so far as they refer not to a stratum co-primordial with the stratum of signifiers, but to the signification (meaning) of subject positions represented by some signifiers that emerge as an effect of material practices of articulation. A subject position, it might be said, is always 'coupled' with some particular set of articulatory practices that defines that position. This coupling, as is frequently said about the coupling of a signifier and a signified in a linguistic sign, might be said to be 'arbitrary', but only in the limited sense that the relationthat of an identity-attained in the subject position between the signifier by which it is represented and the material practices of those identified as such does not express any underlying necessity. Thus, the term that better captures the relation, and the term that in fact actually is central to Laclau's theory, is 'contingent' - a choice of term meant to underscore that while no identity is achieved out of necessity, whichever identity that is actually achieved is not an outcome of pure chance either. But, as hinted by the preceding discussions of the sociality of language, whatever value attained by the linguistic sign, too, is contingent in exactly this sense. For that which effects the shift in value-shifts in the relation between the signifier and the signified-is not pure chance, but some particular series of interactions featuring some particular set of linguistic communities, pluralities of interlocutors and of langues.

The expected end result of processes of shift between the signifiers and the articulatory practices with which they are coupled is some particular fixity of the meaning of subject positions-a fixity that, however, could always be dislocated and undone, hence depriving any result of a genuine finality. ' $[\mathrm{A}] \mathrm{s}$ every subject position is a discursive position', Laclau and Mouffe argue, 'it partakes of the open character of every discourse; consequently, the various positions cannot be totally fixed 
in a closed system of differences'. ${ }^{40}$ What they call 'hegemony' consists fundamentally in attempts to institute a particular fixture of the meaning of elements across various discourses by social actors (such as political movements) through the construction of 'chains of equivalence' between various subject positions - a construction that necessarily takes place, Laclau argues, around some central signifier representing the equivalential relation. In the construction of a chain of equivalence, what is attempted is a subversion of differences between subject positions by emphasizing a certain sameness between them. ${ }^{41} \mathrm{~A}$ hegemonic political practice seeks to 'establish a chain of equivalence among the different democratic struggles so as to create an equivalent articulation' between a plurality of disenfranchised groups and their political demands. ${ }^{42}$

Although hegemony implies that the articulatory practices of multiple subject positions are made alike by the establishment of an equivalential relation between those positions, Laclau and Mouffe emphasize that the equivalence that sustains hegemonic politics is not simply a 'class alliance', in the sense of a "coincidence of interests" among preconstituted agents', ${ }^{43}$ for the identities of those subject positions-and the set of articulatory practices that defines them-are transformed in the very process of establishing the equivalential relation. Thus, the construction of equivalence yields a novel intersection of subject positions, a new identity that did not exist prior to the construction of that equivalence. This is explained by Laclau and Mouffe with a direct comparison of their idea of equivalence to paradigmatic relations in structural linguistics:

The logic of equivalence is a logic of the simplification of political space, while the logic of difference is a logic of its expansion and increasing complexity. Taking a comparative example from linguistics, we could say the logic of difference tends to expand the syntagmatic pole of language, the number of positions that can enter into relation of combination and hence of continuity with one another; while the logic of equivalence expands the paradigmatic pole-that is, the elements that can be substituted for one another-thereby reducing the number of positions which can possibly be combined. ${ }^{44}$

The term 'paradigmatic' is not used by Saussure himself, whose preferred vocabulary, as seen before, is 'associative'. Whatever salient differences there are between the two terms shall be disregarded here-it 
suffices to say that the process of constructing an equivalential chain for Laclau is the expansion of the paradigmatic dimension, and that expanding the paradigmatic dimension corresponds to expanding the associate family of terms in Saussurean linguistics. With this, all the grounds needed to assert the following thesis on the confluence of Saussurean linguistics and hegemonic politics have been laid down: articulating a chain of equivalence in the social space implies a certain reconfiguration of the multiplicity of langues instantiated therein.

The thesis shall be explained with the help of a simple example, a sketch of just one of the many ways in which the articulatory practices of different subject positions may come to be alike, as needs to happen in the creation of equivalence between those subject positions according to Laclau's discourse theory. An individual who has identified with a particular subject position, say, of the 'informal worker', would construct with ease a sentence such as 'I stand for the informal workers'. After a chain of equivalence has been established, for instance, through a popular mobilization, between the positions represented by signifiers 'informal worker', 'the ninety-nine percent', and 'the working class', the same individual will have come to utter 'I stand for the working class' or 'I represent the ninety-nine percent' just as naturally as he could 'I stand for the informal workers'. In this case, it may be supposed that the terms 'the working class', 'the ninety-nine percent', and 'informal worker' have come to be interchangeable for the individual through articulatory practices of a popular mobilization, and that one of the three terms likely will call up into the mind of that individual the other two. It has been argued that in order for terms to belong to the same associative group, the langue of the speaker has to be such that there is a conceptual co-extensiveness between the parts of the conceptual mass coupled with those terms. Now, achieving this co-extensiveness can be understood as precisely the operation in the domain of language proper that corresponds to the construction of equivalence between subject positions in hegemonic politics. Constructing an equivalential chain between a plurality of subject positions involves a reconfiguration of the langues of those individuals who identify with the subject positions in question, such that the terms which are the names of those positions become constituents of a common associative family. 
This reconfiguration cannot be conceived separately from the concrete interactions that must have occurred between individuals occupying different positions. In effect, any political movement whose socially transformative objective presupposes the creation of an expansive political front must interact with those who are attuned to a variety of heterogeneous langues, and attempt to reconfigure those langues so that the terms that signify a plurality of subject positions will have become interchangeable in social and political situations.

\section{Conclusion}

As discourses are for Laclau, a langue is permanently exposed to the possibility of reconfiguration, in so far as the presence of heterogeneous langues is maintained in a language community that, indeed, can only be said to exist 'perfectly' in its plurality and plasticity. Not only does this thesis drawn from the Saussurean text constitute the basis of a counterargument against the charge of 'inconsistency' in the Saussurean concept of the sign, it also points to the social and political implications - and it would not be an exaggeration to say that these implications are democratic_of Saussure's theorization of language that are often underestimated. Reflections on associative groups, social interaction, and the situational reconfigurability of an individual's langue found in the Saussurean text compose the beginnings of a systematic account that may be able to explain how the occupation of a particular subject position or identification with a particular political movement could influence what is said and is sayable by that individual. What, then, remains to be said of the unregulated, unpredictable 'whims' that Laclau regards as that from which utterances of the 'omnipotent' Cartesian subject allegedly presupposed by Saussurean linguistics emanate?

Someone placed in an extremely restrictive situation, such as a political prisoner who has been imprisoned for many years, would be incapable of the kind of articulation that is socially consequential in any immediately obvious way. The utterances and actions of persons in such circumstances will likely be limited to mere repetitions of what they have been permitted to speak and do. Under such a condition, an individual appears to have little prospect of doing something with language that effects a reconfiguration of langues, which, this paper has suggested, is implicated in 
socially transformative articulations. But Saussure, at one point, remarks that the terms in an associative family occur neither in fixed numbers nor in a definite order', adding that 'we are unable to predict the number of words that the memory will suggest or the order in which they will appear. ${ }^{45}$ A small window of possibility is opened by the unpredictability of what will be brought to mind of the speaker. Even when a certain langue has become ingrained in the minds of speakers, there is a chance, that by a fortuitous accident in thought-'All Thought emits a Throw of the Dice [Toute pensée émet un Coup de Dés]', as Mallarmé had written-it will occur to them that some words can be used differently. In so far, however, it is nothing but the fleeting, aleatory moment in thought on which the possibility of a different use of words depends, the parole by which that possibility is materially actualized is likely to bear the outward appearance of an unconditioned 'whimsical' vocalization. Yet, if for this reason some 'Cartesian omnipotence of the subject' were imputed to those who find themselves subjected to heteronomy to an extreme extent, that imputed 'omnipotence' could refer to nothing else than the indomitable freedom in thought. And this idea of the subject's freedom, it might be suggested, is not altogether distant from what Jacques Lacan had proposed as the margin of freedom that is retained by the subject of the signifier despite its alienation in language, ${ }^{46}$ and the concomitant possibility of the subject to act in defiance of established meanings rather than 'act out' in accordance with the expectations of the Other, precisely by using signifiers differently, in ways that may initially be perceived by others as nonsensical. ${ }^{47}$ What had been used as a derogative epithet, then, may well designate the kernel of freedom that cannot be forfeited by those who believe that anyone is capable of starting a revolt in thought, even under the most inhospitable of material conditions.

\section{References:}

Althusser, Louis. Lenin and Philosophy and Other Essays. Trans. Ben Brewster. New York: Monthly Review Press, 2001.

Caws, Peter. Structuralism: The Art of the Intelligible. London: Humanities Press, 1990. 
Karatani, Kojin. Transcritique: On Kant and Marx. Translated by Sabu Kohso. Cambridge, MA: The MIT Press, 2005.

Lacan, Jacques. Écrits: The First Complete Edition in English. Trans. Bruce Fink. New York: W. W. Norton \& Company, 2007.

- The Seminar of Jacques Lacan Book XI: The Four Fundamental Concepts of Psychoanalysis. Ed. Jacques-Alain Miller. Trans. Alan Sheridan. New York: W. W. Norton \& Company, 1998.

Laclau, Ernesto. "Discourse." In A Companion to Contemporary Political Philosophy. Ed. Robert E. Goodin, Philip Pettit, and Thomas Pogge, 1:541-547. 2 $2^{\text {nd }}$ Edition. Oxford, UK: Blackwell, 2007.

-. "Glimpsing the Future." In Laclau: A Critical Reader. Ed. Simon Critchley \& Oliver Marchart, 279-328. New York: Routledge, 2004. Laclau, Ernesto, and Chantal Mouffe. Hegemony and Socialist Strategy: Towards a Radical Democratic Politics. 2n Edition. London: Verso, 2001.

Mouffe, Chantal. The Return of the Political. London: Verso, 2006.

Pluth, Ed. Signifiers and Acts: Freedom in Lacan's Theory of the Subject. Albany, NY: State University of New York Press, 2008.

Price, Brian, and Meghan Sutherland. "Not a Ground but a Horizon: An Interview with Ernesto Laclau." World Picture 2 (Autumn 2008). Access: 18.09.2017. http://www.worldpicturejournal.com/WP_2/ Laclau.html.

Saussure, Ferdinand de. Course in General Linguistics. Ed. Charles Bally, Albert Sechehaye, \& Albert Reidlinger. Trans. Wade Baskin. $3^{\text {rd }}$ Edition. Glasgow, UK: Fontana/Collins, 1978.

- Saussure's Second Course of Lectures on General Linguistics (1908-09):

From the Notebooks of Albert Riedlinger and Charles Patois. Ed. Eisuke Komatsu \& George Wolf. Oxford, UK: Pergamon, 1998.

- Writings in General Linguistics. Ed. Simon Bouquet \& Rudolf Engler. Oxford, UK: Oxford University Press, 2006.

Thibault, Paul J. Re-Reading Saussure: The Dynamics of Signs in Social Life. New York: Routledge, 1996.

Žižek, Slavoj. "Beyond Discourse-Analysis." New Reflections on the Revolution of Our Time. Ed. Ernesto Laclau, 249-260. London: Verso, 1990. 


\section{Endnotes:}

1 Lecturer, Department of Religious and Cultural Studies, Sanata Dharma University. E-mail: minseong.kim@usd.ac.id.

2 Ernesto Laclau, "Discourse," A Companion to Contemporary Political Philosophy, ed. Robert E. Goodin, Philip Pettit, \& Thomas Pogge, $2^{\text {nd }}$ Ed., Vol. 1 (Oxford, UK: Blackwell, 2007) 542.

3 Paul Thibault's monograph represents one of the handful of exceptions to this tendency. See Paul J. Thibault, Re-Reading Saussure: The Dynamics of Signs in Social Life (New York: Routledge, 1996).

4 Ferdinand de Saussure, Course in General Linguistics, ed. Charles Bally, Albert Sechehaye, and Albert Reidlinger, trans. Wade Baskin, 3rd ed. (Glasgow, UK: Fontana/Collins, 1978) 50-51.

5 Peter Caws, Structuralism: The Art of the Intelligible (London: Humanities Press, 1990) 111.

6 Laclau, "Discourse," 542.

7 Jacques Lacan, Écrits: The First Complete Edition in English, trans. Bruce Fink (New York: W. W. Norton \& Company, 2007) 324.

8 Saussure, Course in General Linguistics, op. cit., 111.

9 Ferdinand de Saussure, Writings in General Linguistics, ed. Simon Bouquet and Rudolf Engler (Oxford, UK: Oxford University Press, 2006) 51.

10 Kojin Karatani, Transcritique: On Kant and Marx, trans. Sabu Kohso (Cambridge, MA: The MIT Press, 2005) 230.

11 Ibid.

12 Ibid., 79.

13 Ibid.

14 Saussure, Course in General Linguistics, op. cit., 160.

15 Saussure, Writings in General Linguistics, op. cit., 53.

16 Ibid., 52.

17 Ferdinand de Saussure, Saussure's Second Course of Lectures on General Linguistics (190809): From the Notebooks of Albert Riedlinger and Charles Patois, ed. Eisuke Komatsu and George Wolf (Oxford, UK: Pergamon, 1998) 12; translation modified.

18 Saussure, Course in General Linguistics, op. cit., 78.

19 Saussure, Writings in General Linguistics, op. cit., 222.

20 Ibid., 218.

21 Saussure, Course in General Linguistics, op. cit., 14.

22 Slavoj Žižek, "Beyond Discourse-Analysis," New Reflections on the Revolution of Our Time, ed. Ernesto Laclau (London: Verso, 1990) 249.

23 Saussure, Writings in General Linguistics, op. cit., 226.

24 Ibid.

25 Brian Price and Meghan Sutherland, "Not a Ground but a Horizon: An Interview with Ernesto Laclau," World Picture 2 (Autumn 2008); http:/ /www.worldpicturejournal. com/WP_2/Laclau.html (access 18.09.2017). 
26 Saussure, Course in General Linguistics, op. cit., 121.

27 Nikolai Trubetzkoy, as quoted in Caws, Structuralism, 87.

28 Saussure, Writings in General Linguistics, op. cit., 39.

29 Ibid., 51.

30 Saussure, Course in General Linguistics, op. cit., 125.

31 Ibid., 126.

32 Laclau, "Discourse," 543.

33 Ibid.

34 Ernesto Laclau and Chantal Mouffe, Hegemony and Socialist Strategy: Towards a Radical Democratic Politics, 2nd ed. (London: Verso, 2001) 96.

35 Ibid., 105.

36 Ibid., 107.

37 Ibid., 115.

38 Louis Althusser, Lenin and Philosophy and Other Essays, trans. Ben Brewster (New York: Monthly Review Press, 2001) 114.

39 Ernesto Laclau, "Glimpsing the Future," in Laclau: A Critical Reader, ed. Simon Critchley and Oliver Marchart (New York: Routledge, 2004) 316.

40 Laclau and Mouffe, Hegemony and Socialist Strategy, op. cit., 115.

41 Ibid., 128.

42 Chantal Mouffe, The Return of the Political (London: Verso, 2006) 77.

43 Laclau and Mouffe, Hegemony and Socialist Strategy, op. cit., 58.

44 Ibid., 130.

45 Saussure, Writings in General Linguistics, op. cit., 126.

46 Jacques Lacan, The Seminar of Jacques Lacan Book XI: The Four Fundamental Concepts of Psychoanalysis, ed. Jacques-Alain Miller, trans. Alan Sheridan (New York: W. W. Norton \& Company, 1998) 252.

47 For an account of the Lacanian category of 'act' in relation to freedom, see Ed Pluth, Signifiers and Acts: Freedom in Lacan's Theory of the Subject (Albany, NY: State University of New York Press, 2008). 